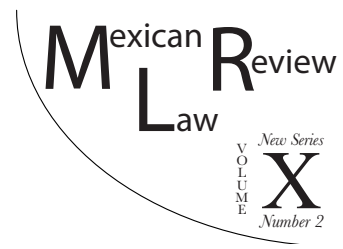

\title{
UNDERSTANDING NAFTA'S ISDS: A CHALLENGE FOR MEXICAN ATTORNEYS
}

\author{
Rosa Haydee Castro PeÑa*
}

\begin{abstract}
In the context of the 20th anniversary of the North America Free Trade Agreement (NAFTA), this article will analyze its Chapter XI: InvestorState Dispute Settlement. Chapter XI embodies the investor's real and practical experience under NAFTA rules. An examination of the historical record demonstrates that Mexican laweyers have been passive participants in defending investors' rights. On the other side of the coin, Mexican investors have not been active participants in NAFTA's Chapter XI, in contrast to Canadian and US investors. Finally, Mexico's experience in international arbitration has not always been negative, but Mexico has been criticized for a lack of transparency and due process for foreign investors.
\end{abstract}

Key Words: NAFTA (North America Free Trade Agreement), ISDS (Investor-State Dispute Settlement), NAFTA-Chapter XI, $20^{\text {th }}$ Anniversary of NAFTA.

Resumen: Tras la celebración del aniversario número 20 del Tratado de Libre Comercio de América del Norte (TLCAN), el siguiente artículo pretende hacer un análisis a su Capitulo XI: Controversias Inversionista-Estado. El Capitulo XI representa, desde una perspectiva práctica y real, la experiencia del Inversionista bajo las reglas del TLCAN. Al realizar un análisis sobre esta experiencia, se logra concluir, que el abogado mexicano ha sido un participante pasivo en defender los derechos de los inversionistas tanto extranjeros, como nacionales. Asimismo y discutiblemente, los inversionistas mexicanos no han sido participantes activos del Capitulo XI del TLCAN, en comparación de los inversionistas extranjeros (Canadá y Estados Unidos de América). Por último, la experiencia que México ha tenido en el campo del Arbitraje Internacional, no siempre ha sido del todo negativa, sin embargo, México se ha visto expuesto por falta transparencia y certeza jurídica hacia el inversionista extranjero.

Palabras Claves: TLCAN (Tratado de Libre Comercio de América del Norte), Inversionista-Estado Controversias, TLCAN-Capitulo XI, Aniversario 20 del TLCAN.

\footnotetext{
* LL. M. in Comparative Law with a concentration in Business and Corporate Law, School of Law, University of San Diego; B.A. in Law, with a minor in Finance. Instituto Tecnológico y de Estudios Superiores de Monterrey.
} 
Esta revista forma parte del acervo de la Biblioteca Jurídica Virtual del Instituto de Investigaciones Jurídicas de la UNAM

\section{Table of Contents}

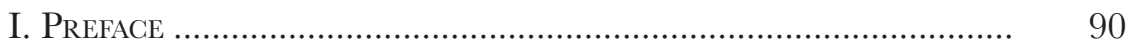

II. What are ISDS's Provisions? ........................................... 93

1. National Treatment............................................................. 94

2. Most-Favored Nation Treatment ....................................... 94

3. Minimum Standard Treatment ........................................ 95

4. Performance Requirements .............................................. 96

5. Senior Management and Boards of Directors..................... 97

6. Transfers ...................................................................... 97

7. Expropriation and Compensation ...................................... 98

8. Exceptions ...................................................................... 99

III. B-Mex Corporations: An Example of ISDS .......................... 102

1. Comparison of B-Mex Case and Past Investor Dispute Controversies Against Mexico ............................................ 104

2 Final Thoughts on B-Mex's Case......................................... 105

IV. FutURE PROJEGTIONS .............................................................. 105

1. What do Past Investor-State Disputes Teach us? .................. 105

2. Mexican Threats to Foreign Investors ................................. 106

3. What can Mexico do to Fully Comply with Ch. XI's rights? . 107

4. What Costs / Benefits has NAFTA's ISDS had for Mexico? .. 109

5. Mexico Has Not Taken Advantage of Ch.XI's Enforcement Mechanism...................................................................... 110

V. Undeveloped Practice Area of Law....................................... 111

VI. Conclusion ........................................................................ 113

\section{PReface}

For Mexican attorneys, the North America Free Trade Agreement (hereinafter NAFTA or the Treaty) has a great deal of connotations. Nonetheless, twenty-two years after the adoption of the Treaty, Mexican attorneys have not developed a well-defined practice area in law, regarding NAFTA's Chapter XI: Investor-State Dispute Settlement (henceforth ISDS), which is one of the most controversial issues in NAFTA.

As NAFTA's procedural history indicates, Chapter XI was a watershed in so far as it implied increase protection for investors (especially against the Mexican authorities) ${ }^{1}$. When NAFTA came into force in 1994, the lack of for-

1 Alejandro Faya Rodríguez, A Quince años del capítulo XI DEl tlaAn, (Universidad Iberoamericana, bepress, 2008), http:// https://works.bepress.com/alejandro_faya_rodriguez/1/ 
Esta revista forma parte del acervo de la Biblioteca Jurídica Virtual del Instituto de Investigaciones Jurídicas de la UNAM

eign investment legislation, the mandatory joint venture requirements with a majority Mexican ownership, and the uncertainty that foreign investors faced in Mexico, all led to the creation of NAFTA's Chapter XI.

But the main reason why ISDS was enforced in NAFTA was to protect investors from expropriations or nationality-based discrimination. Currently, ISDS is often used for disputes claiming unfairness in the behavior of the government, ${ }^{2}$ which has made the United States (hereinafter U.S.) the most sued party (which was actually not considered a threat to foreign investments back in the 1990's).

In the twenty-second anniversary of NAFTA, regarding Investor-State disputes, Mexico has received 22 claims from the U.S. government, and five from the Canadian government. ${ }^{3}$ In contrast, the U.S. has put forward 35 complaints against Canada. ${ }^{4}$ Mexico has only brought two complaints under NAFTA's Chapter XI, one against Canada and one against the U.S. ${ }^{5}$ Why have Mexican Foreign Investors not taken advantage of their NAFTA rights?

The International community has a two-sided opinion concerning ISDS. First, ISDS can be seen as a threat for State's sovereignty, especially on environmental or health matters ${ }^{6}$ (Tobacco companies suing against tobacco health regulations, for instance). Indeed, there is a vast amount of discussions about the need for a change of ISDS's pact terms. Second, ISDS is also viewed as a way to push underdeveloped countries to have a fairer legal system by encouraging alternative means of disputes solutions, for example, under NAFTA's Ch. XI, ISDS is solved through arbitration by international panels. ${ }^{7}$

Investor-State disputes play an important role for the international community. NAFTA was the first international trade treaty to protect foreign investors when they participate abroad. It enacted a law enforcement mechanism that gives investors the capacity to ask the foreign government to view its investment as if it was national. Nowadays, Mexico has over 49 trade treaties

2 Simon Lester, The world has changed. Why haven't our trade deals?, Washington Post: In Theory, Sept. 14, 2016, available at https://www.washingtonpost.com/news/ in-theory/wp/2016/09/14/the-world-has-changed-why-havent-our-trade-deals/?utm_ term $=.8 \mathrm{a} 7 \mathrm{e} 375930 \mathrm{fb}$

3 It is important to highlight that not all of the claims have reached Arbitrational Panels.

4 Publicaitizen, Table of Foreign Investor-State Cases and Claims Under Nafta And Other U.S. "Trade" Deals, (2017), available at http://www.citizen.org/documents/investor-state-chart.pdf

5 Naftaclaims.com, Todd Weiler, (Aug. 20, 2017), available at http://www.naftaclaims.com/ disputes-with-mexico.html

6 Bilaterals.org., Key cases, from available at http://isds.bilaterals.org/?-key-cases (Aug. 20, 2017)

7 See:, Francisco González de Cossío, Arbitraje de Inversión y América Latina, 39 Revista Jurídica: ANUARIO DEL DEPARTAMENTO DE DERECHO DE LA UNIVERSIDAD IBEROAMERICANA (2009). The author points out that arbitration panels are not always the best way to solve international disputes, due to the fact that, through an arbitration panel, society is affected because legal matters become public. Furthermore, international panels may result in diplomatic and political tension. 
Esta revista forma parte del acervo de la Biblioteca Jurídica Virtual del Instituto de Investigaciones Jurídicas de la UNAM

with different countries ${ }^{8}$ where similar rights are granted to foreign investors. In other words, NAFTA's Chapter XI is the model for investor protection in various free trade agreements. ${ }^{9}$

Particularly for Mexico, Investor-State Dispute Settlements are becoming more accessible because of Mexico's new openness to foreign investment in particular sectors which were previously reserved for domestic corporations. The recent reform of Articles 20 and 21 of the Hydrocarbons Law opens the energy sector to foreign participation through different types of contracts, some of which may qualify as investments under NAFTA's Ch. XI. Recently, Bradly J Condon (2016) concluded that foreign investors may have access to pursue Investor-State arbitration covered by NAFTA's Ch. XI, now within the Hydrocarbons sector, as a consequence of the openness to foreign investment in that sector. ${ }^{10}$ According to this idea, Mexico's new access to foreign investment may result in more Ch. XI's dispute settlements in the future.

Undoubtedly, free trade agreements now represent a priority issue for countries around the world. Globalization and the accessibility through the internet to worldwide markets have encouraged states to reconsider protectionism. In this sense, a new area of law is being created encouraging attorneys to develop expertise to offer their local investors the opportunity to exploit their rights in a trade partner-foreign jurisdiction.

From a Mexican perspective, the absence of training in alternative dispute settlements has discouraged the growth of law firms with expertise in foreign investment arbitrational panels. Sadly, foreign investors often have to look outside Mexico for well-prepared attorneys.

In developing this article, I contacted Francisco Cortina Velarde, ${ }^{11}$ Foreign Affairs Mexican attorney and partner of one of the largest Legal Firms in Mexico-Chevez, Ruiz, Zamarripa y Cía. I also consulted with Hugo

8 ProMexico, (May, 2017), available at http://www.promexico.gob.mx/en/mx/tratadoscomerciales

${ }^{9}$ See: FAYA, supra note 1 . The author relates the foreign investment success of NAFTA in Mexico, with the measures given to investors by Chapter XI. Faya concludes that countries with free trade agreements providing investment rights with an enforcement mechanism, such as NAFTA's Chapter XI, encourage and stimulate foreign investors to invest in a partner trade country.

10 Bradly J. Condon, Mexican energy reform and NAFTA Chapter XI: Articles 20 and 21 of the Hydrocarbons Law and access to investment arbitration, 9(3) Oxford: Journal of World Energy Law and Business, 203-218 (2016), available at https://doi.org/10.1093/jwelb/jww008

11 Partner in the Trade and Customs area since 2000 at Chevez, Ruiz, Zamarripa y Cia. His practice includes: customs law, indirect taxes related with trade \& customs operations, international trade law, free trade agreements and procedures under wTO. Mr. Cortina headed the Foreign Trade Commission of the International Chamber of Commerce Mexico (ICC) in 2003; he is in the list of panelists for dispute resolution under Chapter IXI of NAFTA. Mr. Cortina is listed as noted T\&C lawyer by: Legal 500, Chambers, Who's who legal and Latin Lawyer currently during the last decade, (May, 2017), available at http://www.chevez.com/ ingles $/$ index.asp?action $=$ content.detail $\& \mathrm{pID}=175 \& \mathrm{id}=108$ 
Esta revista forma parte del acervo de la Biblioteca Jurídica Virtual del Instituto de Investigaciones Jurídicas de la UNAM

Perezcano, ${ }^{12}$ former General Counsel for International Trade Negotiations, who worked for Mexico's Secretary of Economy for 20 years and represented Mexico in all the dispute settlement proceedings under trade and investment agreements from 1994 through 2006. Later in the article, I will quote them and share their ideas on the lack of Mexican expertise regarding Ch. XI of NAFTA with regard to why Mexican corporations and foreign investors are going outside Mexico to look for legal advice on investment arbitration disputes.

The scope and aims of this article are to look at NAFTA's ISDS from a Mexican perspective, in order to address the following issues:

1. Positive or negative outcomes for the Mexican government,

2. Is it an undeveloped practice area of law among Mexican attorneys?

3. Is the expertise already there, and if not where could we find it?

In this regard, I will first start with the basic ISDS' concepts, followed by the analysis of an example in order to acknowledge what a foreign investor will face in suing Mexico. This will be followed by a future projection on the matter, and a conclusion will then be reached.

\section{What ARE ISDS's Provisions?}

Investor-State Dispute Solutions provisions are, put simply, a set of rights given to investors and their investments, which are enforced by a mechanism recognized by three contracting parties. That is to say, an investor from Canada, the U.S. or Mexico can use this enforcement mechanism to be entitled to receive damages from the foreign jurisdiction, in case of any breach of that set of important rights. Finbow (2016, p. 66) defines ISDS as a mechanism that creates processes whereby states can be directly challenged by actual or potential investors over loss of real or anticipated profits. ${ }^{13}$

12 Cigi Portal. Hugo Perezcano, is deputy director of international economic law with the International Law Research Program (ILRP) and was previously a CIGI senior fellow with the ILRP. Prior to joining CIGI, he was an attorney and international trade consultant in his private practice. Perezcano worked for the Mexican government for nearly 20 years. He was head of Mexico's Trade Remedy Authority, within the Ministry of Economy, and was lead legal counsel for the country's Ministry of Trade and Industrial Promotion, which included work on free trade, dispute settlements, investment, and international agreements joined by Mexico. He participated actively in the North American Free Trade Agreement (NAFTA) and Uruguay Round negotiations, and was Mexico's lead counsel in disputes brought under trade and investment agreements", (Aug., 2017), available at https://www.cigionline.org/person/ hugo perezcano-diaz

13 Robert G. Finbow, Restructuring the State Through Economic and Trade Agreements: The Case of Investment Disputes Resolution, 4 (Cogitatio: Politics and Governance 2016), available at http://www.cogitatiopress.com/politicsandgovernance/article/view/639 
Esta revista forma parte del acervo de la Biblioteca Jurídica Virtual del Instituto de Investigaciones Jurídicas de la UNAM

It is important to consider who is entitled to this set of rights. Investors organized and formed by the laws of the contracting party (Mexico, Canada, U.S.) will be entitled to protection under the ISDS's provisions. Under this idea, corporations, partnerships, trusts, sole proprietorships, joint ventures and business associations for profit or non-profit, are protected under ISDS.

Investor-State provisions are found in Chapter XI of the North America Free Trade Agreement. The Chapter is divided in two sections: investment rules and the settlement of investment disputes' provisions.

First, I will discuss seven important rights that are recognized in NAFTA's Chapter XI within the sections of the investment rules. This will be followed by an examination of specific exceptions to protection.

\section{National Treatment}

Under NAFTA's Article 1102, the right to be treated as "national" and not "foreign" is recognized. In this sense, the contracting parties no longer have foreign investments regarding themselves; this is the core idea of a national treatment's right. It is important to highlight that Mexico has been sued 27 times $^{14}$ (under this most used provision) for a violation of the national treatment right. ${ }^{15}$

The governments of the contracting parties are required by Article 1102 to grant foreign investors/investments a treatment no less favorable, which under the same circumstances would be provided to their national investors regarding establishment, acquisition, expansion, management, conduct, operation, sale or any other disposition of investments.

Under this idea, States cannot impose on any foreign investment additional requirements that a national investment is not required to comply with. NAFTA's Article 1102 gives some examples of this situation: impose on an investor a requirement that a minimum level of equity should be held by nationals, and the requirement to sell or dispose an investment by the mere characteristic of being a foreign investment.

Related to the above, Article 1111 provides that the parties may require a foreign investment to provide routine information concerning their investment in their territory. This will not be considered a breach of Article 1102 (wherein the State is obliged to protect the business information and to acknowledge its confidentiality).

\section{Most-Favored Nation Treatment}

Article 1103 on NAFTA's Chapter XI obliges contracting parties to provide to foreign investors no less favorable treatment than that provided to domestic

14 Juan Pablo Hugues Arthur \& Jimena Moreno González, Mitos y realidades del arbitraje inversionista., Estado en el Tratado de Libre Comercio de América del Norte: La experiencia Mexicana, 31(1) ICSID REV. Foreign INV. L.7., 147, 166 (2016).

15 Id. at 4. 
Esta revista forma parte del acervo de la Biblioteca Jurídica Virtual del Instituto de Investigaciones Jurídicas de la UNAM

investors, in like circumstances, with regard to establishment, acquisition, expansion, management, conduct, operation, and sale or any other disposition of investments. Once again, the issue of the meaning of "under the same circumstances" is raised.

Recently, an issue has come up about a Vancouver Property Tax that may violate NAFTA's Chapter XI provisions. ${ }^{16}$ The issue is a new $15 \%$ Vancouver property transfer tax that is levied against foreign, nationals or corporations. We can easily question this issue under the national-treatment right: Is Canada not obliged to avoid making distinctions between a foreign corporation and a national corporation? Expert Canadian lawyers suggest that individual or state-to-state action could be taken under NAFTA.

\section{Minimum Standard Treatment}

The minimum standard treatment right of investors set forth in NAFTA's Article 1105 is an important doctrine in international law, which establishes that the contracting parties must give foreign investors fair and equitable treatment in accordance with international law, and also provide them security and protection at all times.

Regarding the provision on assuring security and protection at all times, states also agreed to provide non-discriminatory treatment in case of an armed conflict or civil strife. It can be very easily implied, that this agreement was established based on Mexico's experience with government instability.

This particular right, based on the Mexican experience, has always been related to Article 1110, which relates to expropriation and compensation ${ }^{17}$. Nonetheless, it opens a lot of discussions based on the ambiguity of the requirements. Thus, we are asked to refer to general principles of international law, which can have a different state-to-state approach. Indeed, the nature of international law governing foreign investments has long been a major subject of debate, and the NAFTA parties addressed this matter by including substantial articles regulating expropriation and compensation. ${ }^{18}$

Metaclad Corporation was the first foreign corporation to sue Mexico under a breach in Article 1105 - the minimum standard treatment - due to local government activity. Metaclad stated that Mexico, through its municipal

16 J. Hainsworth, Vancouver Property Tax May Violate NAFTA, Trade Lawyer Says, Bloomberg Law, (Aug., 2016) available at https://www.bloomberglaw.com/search/results/814c 5717508 dce 427041486c2f08ec4a/document/X1 OG3CFS000000?search32=7uAlJRZFqDh9vg90APaKA==SwO0ZicY1bhFFL-bPQ73obfJ5139y26PMlCBr6hvU7KKSa6mNksuyi5vglL6esZI

17 Metaclad Corporation v. Estados Unidos Mexicanos, Case No ARB(AF)/97/1, Certified Award, (ICSID. 2000), available at http://naftaclaims.com/disputes/mexico/Metalclad/ MetalcladFinalAward.pdf

18 RalPh H. Folsom, NAFTA AND FREE TRADE IN THE AMERICAS: A PROBLEM ORIENTED COURSE BOOK 307 (Thomson West, 2nd ed. 2005). 
Esta revista forma parte del acervo de la Biblioteca Jurídica Virtual del Instituto de Investigaciones Jurídicas de la UNAM

government of the State of San Luis Potosí, breached Article 1105 in relation to Article 1110, alleging that the local government did not provide a fair and equitable treatment in intervening with its development and operation of a waste landfill in the aforementioned state. ${ }^{19}$ The International Centre for Settlement of Investment Disputes ultimately ruled in Metaclad's favor, but although the corporation had the federal government's license to operate with toxic substances, the local government did not grant the local construction license and obstructed the corporation's investment.

Metaclad's experience highlights the Mexican perspective. As we will see later, the lack of communication between the federal and local government can be very harmful for the Mexican authorities, and can indeed, be a threat to NAFTA's Ch. XI provisions.

\section{Performance Requirements}

Under NAFTA's Article 1106, States agree to not impose or enforce on any contracting party any commitment in its foreign investment with regard to: exporting a given level amount or percentage of goods or services; domestic content; purchasing or use of preferentially domestic products; relating imports or exports in accordance with foreign exchange inflows of their investment; restricting sales of goods or services in the party's territory unless required by a court or a tribunal; transferring technology or production process in the investment territory, and acting as an exclusive supplier.

Accordingly, the performance requirements prohibit contracting parties to impose any kind of regulations that would trigger an obligation on foreign investors. They also define a set of illegal activities as an example of how governments can violate the performance requirements. Article 1106 has been very controversial under the "Mexican IEPS experience," which is discussed below.

IEPS stands for "Impuesto Especial Sobre Producción y Servicios", a tax amendment made on December 2001, (effective January 2002), as a measure to discourage excessive consumption of high caloric content products. Locally speaking, the constitutionality of this tax has been highly questioned because under the Mexican Constitution Congress is not expressly competent to tax soda beverages. Experts suggest that a Constitutional reform is needed in order to allow for a tax reform in those sectors. ${ }^{20}$

Pursuant to NAFTA's Ch. XI, three companies filed a "notice of intent" alleging a violation in Article 1106 because of the IEPS tax: Archer Daniels, Corn Products International and Cargill. Also, the three foreign corporations alleged damages in relation to their High Fructose Corn Syrup (HFCS)

19 See: Metaclad Corporation c Estados Unidos Mexicanos supra note 17.

20 Angelina Mejía Guerrero, Juzgan Inconstitucionalidad del IEPS. El Universal, Jan. 22, 2002, available at http://archivo.eluniversal.com.mx/finanzas/25318.html 
Esta revista forma parte del acervo de la Biblioteca Jurídica Virtual del Instituto de Investigaciones Jurídicas de la UNAM

production and distribution facilities, due to the IEPS tax $(20 \%$ on soft drinks and syrups). As foreign investors claimed, the imposition of the aforesaid tax resulted in a direct impact on their investment. The tax also related to Article 1102 (national treatment) and Article 1110 (expropriation). ${ }^{21}$ The tribunals concluded that Article 1102 requires a taxation related to an investment, and since IEPS was not targeting only foreign investors, the tax did not violate NAFTA's Article 1106.

\section{Senior Management and Boards of Directors}

Under Article 1107, the parties agreed that there would be no requirements to appoint senior management positions individuals of any nationality. Nonetheless, subparagraph 2 allows for a majority of the board of directors or committees to have certain nationalities, as long as they do not interfere with management or control of the investment.

Article 1107 is a consequence of the pre-NAFTA Mexican provisions. As stated before, foreigners were ordinarily allowed to invest in less sensitive industries up to $49 \%$ of the equity, but were not allowed to participate in the management and administration of the corporation. Nevertheless, the Secretary of Economy reserved the criteria on increasing the ownership percentage when, according to its criteria, the foreign investment would encourage the country's economy.

Presently, Mexico has different criteria regarding foreign investment. Mexico has ten Free Trade Agreements (FTAs) with 45 countries, two Agreements on reciprocal promotion and protection of the investments (APRIs in Spanish) with 33 countries, nine Agreements of Economic Complementation and Partial Agreements with the ALAFI (Latin American Association for Integration). ${ }^{22}$

Mexico is considered one of the countries with one of the highest level of "openness" to foreign investment. NAFTA has played an important role in this regard. With the NAFTA experience, Mexico has been able to take advantage of what has worked and what has not. Finally, as stated before, NAFTA's ISDS have been replicated along the FTAs.

\section{Transfers}

21 Archer Daniels c Estados Unidos Mexicanos, Case No ARB(AF)/04/5, Certified Award, (ICSID. Sept. 26, 2007), available at http://naftaclaims.com/disputes/mexico/ADMTate/ADMTateLyle-Mexico-Award.pdf Corn Products International c Estados Unidos Mexicanos, Case No ARB(AF)/04/01, Partial Award, (ICSID, Jan. 15, 2008), available at http://naftaclaims.com/ disputes/mexico/cpi/CPI-Mexico-MeritsAward.pdf Cargill c Estados Unidos Mexicanos, Case No ARB(AF)/05/2, Certified Award (ICSID, Sept. 18, 2009), available at http://naftaclaims.com/disputes/mexico/Cargill/VF_Cargill_award_redacted_version 1.pdf

22 ProMexico, available at http://www.promexico.gob. $\mathrm{mx} / \mathrm{en} / \mathrm{mx} /$ tratados-comerciales (May, 2017). 
Esta revista forma parte del acervo de la Biblioteca Jurídica Virtual del Instituto de Investigaciones Jurídicas de la UNAM

Under NAFTA Article 1109 each contracting party is obliged to permit free transfers and financial instruments without delay, such as profits, dividends, interests, capital gains, royalties, proceeds form sales, payments, etc. The objective of this set of rights is to make foreign investment easily traded and to discourage any limitations in transferring capital for one state to another.

Recently, big improvements have been made as to transferring data and communication. Perhaps Article 1109 has not played an important role among the contracting parties, but it surely will in the short future. For instance, the Fair and Accurate Credit Transactions Act (FACTA), between Mexico and the U.S., whose purpose is to share financial information about the parties' citizens, because of the increase in foreign investment with the government's purpose to avoid tax fraud. Similarly, the Common Reporting Standard (CRS) will encourage communications regarding foreign investments, where banks will play an important role in providing governments with their investors' information. Notwithstanding, both FACT and CRs have a tax collection incentive, a core idea shared with NAFTA's Article 1109.

\section{Expropriation and Compensation ${ }^{23}$}

Huge disputes have been raised about expropriation and compensation investment rights under NAFTA's Article 1110. Expressly stated, no party may directly or indirectly nationalize or expropriate an investment in its territory or take a measure tantamount to nationalization or expropriation. Exceptions regarding public purpose, on a non-discriminatory basis and with due process, and on a compensation payment, are recognized within NAFTA.

Direct expropriation refers to a situation where the government directly takes the ownership title of the investment or the property's investment. Indirect expropriation is when the government does not directly take ownership of the investment, but through a series of acts, it has the same effect as an expropriation.

As mentioned before, the Metaclad's case alleged expropriation breach, because the local government did not allow the investment to take place because of a series of prohibitions by the municipal government of San Luis Potosi. Mexico was found guilty of making an indirect illegal expropriation,

23 See: Francisco González de Cossío, Medidas Equivalentes a Expropiación en Arbitrajes de Inversión, Instituto de Investigaciones Jurídicas de la UNAM, available at https://archivos.juridicas. unam.mx/www/bjv/libros/6/2815/5.pdf. Where he scrutinizes the expropriation concept through different arbitration panels, reaching a well-approached conclusion of the meaning in various concepts, by analyzing different cases, not only in NAFTA, where the concept has been raised among investors. Also, González de Cossío focuses on the scope of the "measure tantamount" connotation. 
Esta revista forma parte del acervo de la Biblioteca Jurídica Virtual del Instituto de Investigaciones Jurídicas de la UNAM

and compensation was paid (about $\$ 16$ million U.S. dollars). This was the first payment by a State to an Investor under Ch. XI. ${ }^{24}$

Other investors such as Archer Daniels, Corn Product International and Cargill, also alleged that an indirect expropriation was made by the Mexican government. The tribunals ruled in Mexico's favor because the investors held at all times the control and ownership of their investments, and therefore Mexico did not illegally take their investment's economic benefits. ${ }^{25}$

It is important to highlight that any authorized expropriation should result in payment of compensation immediately. As Article 1110 states, compensation will be the equivalent to the fair market value of the expropriated investment immediately before the expropriation took place.

Taking a look at the valuation criteria used in Metaclad, the foreign investor suggested using a discounted cash flow analysis or an actual investment in the landfill value. Mexico suggested using a market capitalization approach or a direct investment value approach to damages. The tribunal agreed to take a fair market value approach in respect to the valuation method. ${ }^{26}$

Expropriation and compensation rights are always raised in ISDS, due to the fact that investors alleging a breach of their NAFTA's right consider that the profits from their investment plan is being threatened, or sometimes it can no longer be recovered.

\section{Exceptions}

Article 1113 sets forth a "denial of benefit" provision. Under this provision, if investors of a non-party (other than Canada or U.S.) own or control the corporation, and the corporation has not substantial business activities in the territory of the party under whose law it is organized, Chapter XI's benefits might be denied. This provision is focused on giving the rights only to investors of the contracting parties.

\section{A. Environment}

The international community critically portrays the ISDS mechanism as a threat to democracy, with a disturbing effect on social and environmental programs and regulations. There is also a constant discussion regarding economies such as the U.S., where there is a vast protection of foreign investors within the national system, perhaps ISDS is not really needed. Community activists have long been arguing that the contracting parties are often relaxed

24 See: Folsom, supra note 18 at p. 188.

25 See: Juan Pablo Hugues Arthur and Jimena Moreno González, supra note 14, at p. 158.

26 See: Metaclad Corporation Estados Unidos Mexicanos, supra note 17, at p. 122. 
Esta revista forma parte del acervo de la Biblioteca Jurídica Virtual del Instituto de Investigaciones Jurídicas de la UNAM

in allowing foreign investments that might compromise public health or the environment. ${ }^{27}$

Under Article 1114, the parties agree that it is "inappropriate" to encourage investment by relaxing domestic health, safety, or environmental measures. In this sense and because of environmentalist activism, the contracting parties adopted the North America Agreement on Environmental Cooperation (NAAEC). Some of the objectives of the side agreement is to "assess, as appropriate, environmental impacts", "promote education in environmental matters", and to ensure that each country "shall ensure that its laws and regulations provide for high levels of environmental protection and shall strive to continue to improve those laws and regulations". ${ }^{28}$

Over the past 22 years, Mexico has made efforts to legislate environmental laws. Mexico now has over sixteen Federal Environmental Laws, a Federal Attorney's Office for Environmental Protection (Procuraduría Federal de Protección Ambiental - Profepa) with a law enforcement mechanism that audits corporations involved in any kind of business that might have an impact on the environment. ${ }^{29}$

In Metaclad, the environmental impact of the investment was highly questioned, and the local municipality denied the operational permit needed, by reference to environmental impact of the waste disposal landfill. Nonetheless, the lack of transparency of the Mexican Government induced the Tribunal to rule in Metaclad's favor. ${ }^{30}$

\section{B. Annex I and III Exceptions}

Under Annex I and III, Mexico made exceptions for some sectors that do not have beneficial rights under Ch. XI.

In the communications sector, reservations were made for: entertainment services, telecommunications, transport networks, postal services, and railroads. In the energy sector for: petroleum and other hydrocarbons, basic petrochemicals, electricity, nuclear power, and treatment of radioactive minerals. Under the transportation sector, the following: specialized personnel (only Mexican nationals by birth may serve as captains, harbor pilots, customs brokers, etc.). ${ }^{31}$

27 Publiccitizen, Investor-State Dispute Settlement (ISDS) Attacks: Empowering Multinational Corporations to Attack our Domestic Lawes, Demand Taxpayer Compensation, (May, 2017), available at http:// www.citizen.org/investorcases

28 Steve Charnovitz, The NAFTA Environmental Side Agreement: Implications for Environmental Cooperation, Trade Policy, and American Treaty making, 8(2) Temple Intl. and COMP. L. F. 257-314 (1994).

29 Profepa (May, 2017), http://www.profepa.gob.mx

30 See: Metaclad Corporation c Estados Unidos Mexicanos, supra note 17, at p. 86.

31 North America Free Trade Agreement, Can.-Mex.-U.S., Dec. 17, 1992, 32 I.L.M. 289 (1993). 
Esta revista forma parte del acervo de la Biblioteca Jurídica Virtual del Instituto de Investigaciones Jurídicas de la UNAM

The settlement dispute's provisions are found in Subpart B of NAFTA's Ch. XI. The following provisions set forth the "due process" of the law enforcement mechanism given to foreign investors, in accordance with the set of rights explained above.

The core of the system is international reciprocity and due process before an impartial tribunal. A three-year window is given to investors to claim a breach and to recover damages under NAFTA's Ch. XI. ${ }^{32}$ Investors acting on behalf of NAFTA enterprises they own or control (directly or indirectly) are also allowed to use ISDS. ${ }^{33}$

All claims are filed against the Federal Government, stating clearly that the breach of NAFTA caused loss or damage to their investment. The first pre-step that parties must follow is set forth in Article 1118, encouraging parties to settle a claim through consultation and negotiations between them.

First, the disputing party must hand in a notice of intent to submit a claim under NAFTA's Ch. XI. This notice should indicate a) the name and address of the disputing investor, $b$ ) the provisions alleged to have been breached, $c$ ) the issues and factual basis of the claim, and $d$ ) the relief sought and the approximate amount of damages claimed.

For Mexico, claims are filed with the Secretary of Economy (Secretaría de Economía) in Mexico City. When the notice of intent is received, the proof of proper filing is a stamp by the Secretary's clerk, which indicates the date and hour of filing.

Second, in connection with Article 1121, a disputing investor must submit a consent and waiver to the other party, where the Investor consents to arbitration in accordance with NAFTA, and waives the right to initiate or continue before any administrative tribunal or court. Nonetheless, Investors may file or seek relief for injunctive, declaratory or other extraordinary relief not covered by NAFTA. ${ }^{34}$

After a six-month period from the events that gave rise to a nonconforming Investor, the disputing party may submit the claim to arbitration under:

— ICSID (International Centre for the Settlement of Investment Disputes) Convention, which only Canada and U.S. have ratified.

- Additional Facility Rules of ICSID, in case both parties are not members of the ICSID Convention.

- uncitral (United Nations Commission on International Trade Law) Arbitration Rules.

\footnotetext{
32 Id. Article 1116.

33 Id. Article 1117.

34 See: Folsom, supra note 18, p. 182.
} 
Esta revista forma parte del acervo de la Biblioteca Jurídica Virtual del Instituto de Investigaciones Jurídicas de la UNAM

The applicable arbitration rules for each tribunal will govern the dispute. The tribunal will have three arbitrators, one arbitrator appointed by each of the disputing parties, and the presiding arbitrator appointed in agreement between the parties. ${ }^{35}$

The Additional Facility of the ICSID has resolved nine cases in which Mexico has been sued, and uncitral has resolved two. At the time, in total eleven investor-State disputes against Mexico have been resolved. ${ }^{36}$ There are three active investor-State cases in conformity with NAFTA's Ch. XI (there are two other investor-State cases in conformity with Trade Agreements of Panama and Spain). ${ }^{37}$

Article 1136 deals with final award provisions. An award made by a tribunal should be binding and fully complied with by the parties without delay. Nonetheless, paragraph 3 specifies that a disputing party may not seek enforcement until, in the case of a final award under the ICSID Additional Facility or the UNCITRAL, three months have elapsed from the date of the rendered award and no disputing party has commenced a proceeding to revise, set aside or annul the award. After the revision mechanism aforementioned, there is no further appeal.

Criticism has been raised questioning the fact that there is no appeal mechanism before another tribunal. ${ }^{38}$ However, ISDS is the investor's best option to find a protection for its foreign investment, given that by the enforcement mechanism States are required to fully comply in case of any damage is sentenced. If a State refuses to comply, it can result in a State-State dispute, governed by Chapter 20 of NAFTA.

\section{B-Mex Corporations: An Example of ISDS}

B-Mex corporations (B-Mex, LLC, B-Mex II, LLC, Palmas South, LLC, Oaxaca Investments, LLC, Santa Fe Mexico Investments, LLC, Gordon Burr, Erin Burr, and John Conley), together as the U.S. investors, represented by White \& Case, LLP, based in Washington, DC, filed a notice of intent to submit a claim to arbitration, under Article 1119 of NAFTA, on May 23rd, 2014.

The corporations invested in gaming facilities in several states of Mexico, and also shared ownership interest in Mexican company "Exciting Games S. de R.L. de C.V." Together as U.S. investors, claimed to be an "investor of a party" under Article 1139 of NAFTA.

In the notice of intent submitted through the Secretary of Economy, the Investors claimed that Mexico, through its federal government and entities,

\footnotetext{
35 NAFTA, supra note 31, Article 1123.

36 See: Juan Pablo Hugues Arthur and Jimena Moreno González, supra note 14, tbls. 164-166.

37 Secretaría de Economía, (May, 2017) http://www.gob.mx/se/acciones-y-programas/ comercio-exterior-solucion-de-controversias.

38 See: Publiccitizen, supra note 27.
} 
Esta revista forma parte del acervo de la Biblioteca Jurídica Virtual del Instituto de Investigaciones Jurídicas de la UNAM

jeopardized their gaming investment even though they had the corresponding operating permit granted by the Secretary of Government (Segob for its acronym in Spanish). Claimants argued that Mexico had, by its actions and omissions, and by the acts of entities and agencies for which it is responsible under Mexican law, caused substantial damage to claimants in breach of Mexico's obligation under NAFTA, destroying a successful gaming business and depriving claimants of the fruits of eight years of investment. To date, five gaming facilities are closed, apparently without a closure order or any other kind of explanation by the corresponding authority; the Investors alleged lack of due process and transparency by the Mexican government.

Investors claimed that Mexico's actions violated multiple provisions of NAFTA, including:

1. Article 1102: National Treatment,

2. Article 1103: Most-Favored-Nation Treatment,

3. Article 1105: Minimum Standard of Treatment, and

4. Article 1110: Expropriation and Compensation. ${ }^{39}$

The relief requested was in the amount of U.S. $\$ 100$ million, and the parties intended to seek post award interest, and all costs and fees associated with the arbitration.

In accordance with Article 1123, claimants chose the Additional Facility of the ICSID as the arbitrator of the dispute. Correspondingly, a Request for Arbitration 2016 was filed on June $15^{\text {th }}$, pursuant to Articles 1116, 1117, $1120(1)(b)$ and 1137 of NAFTA, and Article 2(a) and 4 of the Additional Facility Rules of ICSID.

The investors claimed that the government's unlawful measures included 1) the gaming authority invalidation of a 25-year Casino permit that had been granted to the investor, alleging that another Mexican corporation obtained its permit under identical circumstances and continues to operate through its license; 2) permanent closure of the investor's casinos by an unauthorized authority; 3) temporary closure of the Mexico City Casino; 4) the implementation of retaliatory tax measures aimed to harass Casino's profits; 5) criminal investigations against E-Games (one of the corporations of the investor); and (6) intervention into claimants' efforts to sell or transfer their Casino assets to third parties. ${ }^{40}$

First, claimants alleged that the PRI administration (Mexican political party in office) had framed a campaign against the investor's casinos. The investors claimed that they had suffered discriminatory treatment from the Mexican authorities, especially from the director of the Mexican Gaming Department, who has questioned the legality of the permit granted.

39 B-Mex, et al. c Estados Unidos Mexicanos, Notice of Intent to Submit a Claim to Arbitration Under Chapter Eleven Of the North American Free Trade Agreement, (May 23, 2014), http://naftaclaims.com/disputes/mexico/bmex/bmex-03.pdf

${ }^{40}$ d. at p. 9. 
Esta revista forma parte del acervo de la Biblioteca Jurídica Virtual del Instituto de Investigaciones Jurídicas de la UNAM

The investor also alleged the lack of due process and lack of transparency of the Mexican government, where corruption often plays an important role. In fact, ISDS's enforcement mechanism represents the only scheme of protection for the foreign investor, due that the investor has already pursued protection under federal law (through the writ of amparo).

Investor alleged a breach of Article 1102 of NAFTA, in that other gaming corporations can operate their businesses under the same exact circumstances (precisely, the investor cites the corporation Producciones Móviles). Claimants alleged that the new casino permit was denied on arbitrary and erroneous grounds, while at the same time permits were granted to nationals.

Regarding Mexico's breach of NAFTA's Article 1103, the investor alleged that Mexico refused to grant justice and to ensure a treatment no less favorable than the accorded to other foreign investors. Similarly, claimant alleged that a breach of NAFTA's Article 1105 was made by Mexico because of the supposed arbitrary and discriminatory application of Mexico's Gaming Regulations, enforced by the Segob.

Finally, the investor claimed that a breach of NAFTA's Article 1110 was made by Mexico, because of the closure of the casinos through its institution Segob and the Mexican Judiciary system. The closure of the casinos, which the investor claimed resulted in an expropriation, are alleged to be made with lack of transparency and due process.

This dispute is still in process within the Additional Facility of ICSD. The status of the case is pending following appointment by the respondent Raul E. Vinuesa, who accepted his appointment as arbitrator on October 4, $2016 .{ }^{41}$

\section{Comparison of B-Mex Case and Past Investor Disputes Controversies Against Mexico}

B-Mex allegations resemble claims made by investors in past ISDS under NAFTA. Mexico seems to be sued over and over again under the same grounds. As stated before, Article 1102 of NAFTA is the most cited provision allegedly breached by Mexico.

The lack of transparency and due process were raised by the investors in Metaclad's case, where Mexico breached Ch. XI and had to award U.S. \$16.6 millions. In Metaclad, although the investor had the corresponding license to operate a waste treatment facility, the lack of communications between the federal government and the local authorities, jeopardized the investment and resulted in damages to the foreign investor.

In Cargill, Mexico breached Article 1102 and Article 1105 of nAFTA. The Additional Facility of ICSID determined that Cargill was in "like circumstances" (under NAFTA's Article 1102) with domestic suppliers of cane sugar

41 B-Mex, LLC and others v. United Mexican States, ICsid Case No. ARB(AF)/16/3, Procedural Details (ICSID, May 2017). avilable at https://icsid.worldbank.org/apps/ICSIDWEB/cases/ Pages $/$ casedetail.aspx? CaseNo=ARB $(\mathrm{AF}) / 16 / 3 \& \mathrm{tab}=\mathrm{PRD}$ 
Esta revista forma parte del acervo de la Biblioteca Jurídica Virtual del Instituto de Investigaciones Jurídicas de la UNAM

to the soft-drink industry. Furthermore, the Tribunal concluded that Cargill received treatment no less favorable to that given to domestic suppliers. The Tribunal rationale was that the tax imposed on HFCS was to pressure the U.S. Government and therefore was directed at U.S. producers of HFCS, in breach of NAFTA's Article 1102.

\section{Final Thoughts on B-Mex's Case}

As a Mexican attorney, B-Mex's allegations sound very familiar. Practicing attorneys who deal with federal agencies, and local authorities, regarding permit requirements of any field, face a lack of transparency, due process, and the on going discussion on Mexican corruption.

The gaming industry can be a particularly difficult sector, since it has always been linked to money laundering. Nevertheless, domestic corporations and foreign investors plead with the Mexican government for more legal certainty regarding their businesses. It can be hardly concluded, that if ISDS is taken out of the foreign investor's possibilities, Mexico can be harmed in its foreign investment due that investors will face an insecure investment field. That is to say, the enforcement mechanism represents, sometimes, the only option for investors to be protected under an impartial tribunal.

Mexico has been punished by the international community for a lack of transparency and due process over and over again. This was seen in the Metaclad's case, where a lack of communications between the federal government and local authorities forced the foreign investment to seek damages and to find protection under international law.

\section{Future Projection on the Matter}

Mexico has engaged in multiple trade treaties with ISDS provisions. Conclusions and future projections must be made in order to improve our relation with foreign investors. Based on Mexico's past experiences under Chapter XI of NAFTA, we can come up with some future thoughts and questions can be raised for further analysis.

\section{What do Past Investor-State Disputes Teach us?}

First, the Mexican experience with IEPS and HFCS demonstrates that the idea to "pressure" foreign States through enforcing regulations and denying permits to foreign investors from that State, can result in an economic detriment to the country. Mexico, in fact, has been ordered to pay U.S. \$189.4 millions to Foreign Investors for a breach in NAFTA's Article 1102, 1105, and 
Esta revista forma parte del acervo de la Biblioteca Jurídica Virtual del Instituto de Investigaciones Jurídicas de la UNAM

1106. As Lic. Hugo Perezcano (former Mexican representative in ISDS) shared with me, the Mexican Congress was informed from the beginning that, if it enacted the IEPS, Mexico would likely be in breach of its international obligations, ${ }^{42}$ likewise three suits were brought by Investors against the Mexican government.

Second, the experience in Metaclad helps us to better analyze what investors face in Mexico. In Metaclad, the lack of communication between the federal government (who granted the operation permit to the corporation) and the tribunal concluded that, when dealing with the operation of an investment, NAFTA foresees that there should be no room for doubt or uncertainty on any matters. Moreover, the tribunal highlighted that if the federal government becomes aware of any scope for misunderstanding or confusion (regarding the local authorities), it has a duty to ensure that the correct position is promptly determined..$^{43}$

Similarly, in Marvin Roy Feldman's case, the Tribunal concluded that SAT (through its treasury department, or SHCP in Spanish) followed an inconsistent and non-transparent course of action against the foreign investor. In this dispute, ISDS was the last course of action that the investor had because a writ of amparo was already pursued by the Investor. Here, Mexico was ordered to pay $\$ 1.9$ millions USD for a breach of NAFTA's article $1102 .{ }^{44}$

Regarding the relationship between the Mexican government and investors, Hugo Perezcano believes that using investor-State arbitration was a losing proposition for both parties: In general, investors have been awarded much less than what they have claimed to be adequate compensation for the loss or damage incurred (around 10\% of the amount claimed, as he recalled). From a business point of view, an ongoing business will generally be more profitable than collecting damages. For the State, wining may mean that it does not have to pay any damages, but it will have incurred the cost of litigation and, more often than not, it will entail the loss of an investment in its territory. ${ }^{45}$

To conclude, Mexico can learn and improve from past Chapter XI's controversies. The illustrated cases allow us to re-consider what we are missing as a country, and what we can do to improve a healthy investment environment. ${ }^{46}$

42 Interview with Hugo Perezcano (November, 2016).

43 See: Metaclad Corporation c Estdados Unidos Mexicanos, supra note 17, at p. 76.

44 Marvin Feldman Estados Unidos Mexicanos, Case No ARB(AF)/99/1, Certified Award (ICSID, August $\left.30^{\text {th }}, 2000\right)$, http://naftaclaims.com/disputes/mexico/Feldman/FeldmanFinalAward.pdf

45 See: Perezcano, supra note 42.

46 Francisco González de Cossio, Arbitraje de Inversión Á la Mexicaine, Instituto de Investigaciones Jurídicas de la UNAM, available at https://revistas-colaboracion.juridicas.unam.mx/ index.php/juridica/article/viewFile/11594/10605. The author concludes that the defense approached by the SE, by 2005, regarding the 15 cases solved at that time, was excellent. He considers that through the cases solved by an impartial tribunal, in which Mexico has been involved, the concepts have been scrutinized, and therefore, they have left a legal precedent among the international community. 
Esta revista forma parte del acervo de la Biblioteca Jurídica Virtual del Instituto de Investigaciones Jurídicas de la UNAM

\section{Mexican Threats to Foreign Investors}

Having analyzed the resolved cases, the first threat that foreign investors face among Mexican authorities is the non-transparency of their processes, the deficiency of due process, and legal uncertainty. Tribunals, in resolving investor-State disputes, have scrutinized the matter more than once; Mexico has been punished for its internal affairs and communications between the foreign investor and their federal/local agencies. The internal affairs and communications have been non-transparent and the investors claimed to face doubt and legal uncertainty on their investments.

In Metaclad, the Tribunal stated that "Mexico failed to ensure a transparent and predictable framework for Metaclad's business planning and investment. The totality of these circumstances demonstrates a lack of orderly process and timely disposition in relation to an investor acting in the expectation that it would be treated fairly and justly in accordance with NAFTA." ${ }^{47}$

As we can conclude, the doubt and legal uncertainty that foreign investors face in dealing with the Mexican federal government can drive them to seek international protection. They want to ensure that their investment is being remunerated due to the fact that it is been obstructed by the Mexican government.

The second threat that foreign investment faces are local authorities in the rural communities where they invest. Specifically, in Metaclad, the local government interfered with its development and the operation of the waste landfill. The local government took actions such as blocking traffic into and out of the site and, therefore, the corporation was prevented from opening the landfill. Moreover, the local population took actions that forced the town council to deny the local construction permit and consequently amounted to an indirect expropriation of Metaclad's investment.

It is important to highlight that local governments (including municipalities) are subject to NAFTA standards. Mexico is obliged to enforce its communications with local authorities in order to avoid conflicts with foreign investors.

The third threat is the lack of expertise among Mexican attorneys. Foreign investors do not find corresponding knowledge in Mexican legal firms when facing a controversy with the federal government. The kind of expertise that investors look for should be firms with a legal proficiency in arbitration panels and NAFTA's dispute resolutions.

There have been 11 NAFTA's investor-State disputes against Mexico; all of them have been represented by an International Legal Firm. Why have Mexican Legal Firms not played an important role in NAFTA's ISDS? One reason is that the skill is not there. After 22 years of NAFTA, many foreign investors would rather hire a U.S. legal firm. Perhaps foreign investors prefer a non-Mexican legal firm because they believe that Mexican legal firms will "protect" the Mexican side, and as well, there is a fear of non-transparency and corruption.

${ }^{47}$ See: Metaclad Corporation c Estados Unidos Mexicanos, supra note 17, at p. 99. 
Esta revista forma parte del acervo de la Biblioteca Jurídica Virtual del Instituto de Investigaciones Jurídicas de la UNAM

\section{What Can Mexico do to Fully Comply With Ch. XI's Rights?}

When Mexico adopts international treaties, it should not over-think the ISDS provisions, because foreign investment is worth risking expenditures in awarding foreign investors. Nonetheless, a compliance mechanism is missing among Mexican authorities to fully adhere to its foreign investment commitments.

It can be concluded that, from the ISDS cases, Mexico should already understand the economic consequences that the enforcement mechanism represents. Under this idea, Mexico should provide a safer environment to foreign investors with the aim to avoid future conflicts.

With this in mind, it is clear that Mexico is being asked to enforce its internal affairs in order to fully comply with NAFTA's provisions. The Mexican federal government, through its Secretary of Economy, should improve transparency, due process, and expedite communication when dealing with foreign investors in order to avoid future conflicts. After all, Mexico negotiated NAFTA terms and its Chapter XI to provide economic stability in the long run based on open frontiers and free trade. That is to say, Mexico probably knew that the government (Congress and politicians) can engage in acts that compromise Mexico's international obligations, and therefore, ISDS may be viewed as a way to "tie the hands" of government acts and its constant change because of different political ideas. ${ }^{48}$

For instance, what if foreign investors only deal with federal agencies rather than local authorities? This idea could be implemented in order to avoid local governments jeopardizing foreign investments that have been granted the corresponding permits from the federal government. Sometimes, when foreign investment arrives in a local community, a sense of nationalism is awakened among the residents of that community. This can be very harmful to the foreign investor, since the residents engage in activities to obstruct their projects and investment (see Metaclad). However, due to the Mexican federal system, it will be very hard to implement it.

Local agencies and municipal entities likely do not know about trade treaties and foreign investor's rights. One solution can be the approach by the Secretary of Economy, through workshops and trainings, with local agencies and municipalities to inform and teach them about how to approach foreign investors, and essentially who to approach in case of any dispute. ${ }^{49}$

However, ISDS is an international issue. I believe that it is also a matter of local culture. If Mexican authorities struggle with corruption, transparency and due process can never be achieved. Therefore, it can be question why the federal government keeps signing trade treaties with ISDS provisions, if they cannot assure a secure investment environment to foreign investors.

48 See: Perezcano, supra note 42.

49 Id. This solution was considered by Hugo Perezcano, based on his past experience with the Vietnam government, where he did a training with representatives of local agencies and municipality entities. 
Esta revista forma parte del acervo de la Biblioteca Jurídica Virtual del Instituto de Investigaciones Jurídicas de la UNAM

For instance, Mexico should reconsider which industries may be harmed by foreign investments. With this in mind, perhaps Mexico can assure a healthy foreign investment environment to the industries that the country can fully commit to (for example, it is well-known that the gaming industry has a sense of nationalism, and the community does not want foreign investment in that field). Possibly, Mexico can consider adding more exceptions, under Annex I and III, where some sectors will not have beneficial rights under NAFTA's Chapter XI.

\section{What Costs / Benefits has NAFTA's ISDS had for Mexico?}

Mexico has not been the most-sued party, as it was estimated when the ISDS's provisions where being negotiated. Canada has been sued 32 times, mostly by U.S. investors, and U.S. has been sued 21 times, mostly by Canadian investors. ISDS's provisions have not substantially damaged Mexico in comparison to the benefits that NAFTA brought to foreign investment.

Mexico has been exposed by the tribunals (especially by the Additional Facility of ICSID) in its failures of NAFTA's commitments because of lack of transparency, lack of orderly process, and not providing investors fair and equitable treatment under NAFTA.

I believe this is a cost but also a benefit for Mexico. The economic costs are straight forward, but the benefits can be achieved by evaluating and considering what Mexico can do in order to assure a better investment environment, possibly, requiring agencies to enforce their monitoring and oversight performance when dealing with foreign investors in order to prevent miscommunications. By taking these actions, Mexico can have a positive impact on its performance in diminishing lack of transparency and enforcing due process.

Looking at ISDS concluded cases, tribunals have ruled in Mexico's favor six times out of 11 cases. Nonetheless, looking at the other five cases, Mexico has breached NAFTA's Article 1102 "national treatment" in almost all of the disputes. Tribunals have scrutinized Mexico's breach of Article 1102, concluding once again that the lack of transparency within Mexican agencies have given investors less favorable treatment than the one received by domestic corporations.

Regarding NAFTA's Article 1110 "expropriation," Mexico has been found to violate that provision in Metaclad, through enacting an Ecological Decree (issued by the local authority of the municipality) within the area of the investment and created therein an ecological preserve. The Tribunal held that the Ecological Decree constituted an act tantamount to expropriation, ${ }^{50}$ which obstructed the foreign investor to operate in the landfill.

50 See: Metaclad Corporation c Estados Unidos Mexicanos, supra note 17, at p.111. Tantamount expropriation represented an indirectly expropriation of Metaclad's investment without providing the corresponding compensation foreseen in NAFTA. 
Esta revista forma parte del acervo de la Biblioteca Jurídica Virtual del Instituto de Investigaciones Jurídicas de la UNAM

With this in mind, for certain industries where regulatory legislation is needed in order to enforce safety and healthy environment, ISDS may bear high costs. However, Mexico always has the option and the right to exclude industries from ISDs's rights. Additionally, with Metaclad's experience, Mexico can communicate to possible future investors the areas or reserves it has in order to protect social matters such as the environment.

\section{Mexico has Not Taken Advantage of Ch.XI's Enforcement Mechanism}

Under NAFTA's Ch. XI, Mexico has been sued 22 times. Nevertheless, Mexican corporations have only sued two times: once against U.S., and once against Canada; both of them ended in the "notice of intent to submit a claim to arbitration" with no further progress on the process. ${ }^{51}$ As we may conclude, Mexico's foreign investors do not represent a threat either for Canada or the U.S. Here are the Mexican examples on ISDS:

In March 1996 Signa S.A. de C.V. was the first Mexican corporation to file a notice of intention to submit a claim to arbitration for the breach of Canada's obligation under NAFTA. ${ }^{52}$ Signa claimed to have been prevented by the Canadian government to manufacture a powerful antibiotic for the Canadian marketplace. The investor alleged a breach under NAFTA's Article 1105 and Article 1110 through its Patented Medicines Regulations promulgated on March 1993 by Canada. The investor alleged that it had invested in its factories, equipment and technologies for the purpose of being able to produce and sell pharmaceutical chemicals. Overall, Signa, represented by Appleton \& Associates, a N.Y. based Firm, claimed damages of $\$ 50$ million Canadian dollars. No further documents were exchanged between the parties seeking for arbitration under NAFTA's Ch. XI. As we may recall, NAFTA encourages the disputing parties to reach a settlement by private means of communications; that could have been the case here.

GANAGAR (Cámara Nacional del Autotransporte de Carga by its acronym in Spanish), in May 2009 filed a notice of arbitration against the U.S. in accordance with NAFTA's Article 1119. CANACAR, in representation of the interests of independent trucking companies of Mexico, claimed a breached of NAFTA's Article 1102, 1103, and 1105. The investor claimed that the U.S. violated NAFTA by refusing entry of the trucking companies into the U.S. for provision of trucking services and by prohibiting them from making investments in U.S. Furthermore, CANACAR claimed that U.S. had violated NAFTA's Article 1105 through its refusal to comply with an arbitration opinion "Cross-

51 Naftaclaims.com, Todd Weiler, (May, 2017) http://www.naftaclaims.com/.

52 Signa $v$ Government of Canada. Notice of Intent to Submit a claim to arbitration under section B of Chapter XI of the North America Free Trade Agreement, (March 4, 1996), http:// naftaclaims.com/disputes/canada/signa/signa-01.pdf 
Esta revista forma parte del acervo de la Biblioteca Jurídica Virtual del Instituto de Investigaciones Jurídicas de la UNAM

Border-Trucking, U.S.A-MEX-98-2008-01".53 The arbitration procedure ended with the aforementioned notice of arbitration.

In the Mexican experience, two cases cannot teach us a lot. The fact that both of them were represented by International Legal Firms helps us conclude that perhaps one of the reasons why corporations do not use NAFTA's enforcement mechanism is because they do not find knowledgeable legal support in Mexico regarding ISDS claims.

Considering that Mexico has only sued two times and has never recovered damages from Canada nor the U.S., probably ISDS have only had costs to Mexico without any positive outcome for Mexican investors. It can hardly be said that Mexican corporations do not face NAFTA's issues in their investments, while Canada and U.S. corporations use ISDS constantly in protecting their investments.

Nonetheless, perhaps it is a matter of information and communication. The Mexican government should increase efforts in schemes to allow Mexican foreign investors to access their rights not only under NAFTA, but in every trade treaty. Encouraging this, Mexican corporations can start pursuing their foreign investment rights and probably commence using ISDS's provisions. If the rights abroad are recognized by Mexican corporations, these Firms will be able to sense more security, and have Legal certainty in foreign countries, which will result in a boost of Mexican corporations investing abroad.

\section{Undeveloped Practice Area of Law}

As I have stated in this article, investor-State disputes will keep increasing as a consequence of openness to foreign investments and the enactment of trade treaties. The urge to develop expertise among Mexican attorneys is crucial; Mexican legal firms should engage in ISDS in order to provide all investors legal expertise on the subject matter.

Undoubtedly, there is a lack of arbitration expertise among Mexican attorneys, especially in NAFTA's investor-State dispute settlement. The facts are clear: in 22 years of NAFTA, the participation of Mexican Legal Firms is insignificant, almost null, Mexican corporations are not being active claimants in NAFTA's ISDS, and, lastly overall it is an unknown practice area of law between new generations of attorneys.

Some opinions may suggest that when foreign corporations sue the Mexican government, they will hire local legal firms. However, I would like to consider the advantages of hiring a Mexican legal firm in representing the foreign investor in an investor-State dispute.

53 Canacar $v$ Government of U.S. Notice of Intent to Submit a claim to arbitration under section B of Chapter XI of the North America Free Trade Agreement (April 2, 2009), http:// naftaclaims.com/disputes/U.S.a/Trucking-II/CANACAR-U.S.A-02-04-09.pdf 
Esta revista forma parte del acervo de la Biblioteca Jurídica Virtual del Instituto de Investigaciones Jurídicas de la UNAM

First, Mexican legal firms know how to move around more effectively with Mexican institutions and government agencies. Generally, Mexican legal firms have the expertise in the modus operandi in dealing with Mexican administrative agencies, government institutions, and their processes. As it has been stated, NAFTA's Ch. XI encourages private communications in order to settle disputes before the case is presented before a tribunal. In this sense, Mexican legal firms will be able to provide a better approach, and encourage better communications with Mexican authorities, which can result in a positive outcome for both parties.

Second, and related with the aforementioned, Mexican legal firms can take advantage of their Spanish-speaking partners and eliminate the language barrier in dealing with Mexican governmental agencies. The fact that Mexico is a Spanish speaking country with a civil law can be very difficult for International legal firms, since the due process in handling with governmental agencies can be very different from common law jurisdictions (Canada and the U.S.).

Third, the costs in hiring a Mexican legal firm will be lower. Even though investors can recover legal fees in their claims, there are some costs that cannot be recovered, such as lawyer's travel expenses for going to Mexico to follow up the case. Investors can benefit from Mexican based firms that will not engage in extra expenses in following up the case.

However, if foreign investors do not look at Mexico to find the corresponding legal support, Mexican legal firms will hardly get the expertise. Nonetheless, as ISDS becomes more and more common in resolving foreign investor disputes, the required skills will become a need more than an option. Moreover, if Mexican investors do not use ISDS, Mexican legal firms will not get the opportunity to represent an investor in an arbitrational panel.

Surely, there are many reliable Mexican legal firms trying to move forward to this type of litigation. Francisco Cortina Velarde, foreign trade Mexican attorney from Chevez, Ruiz, Zamarripa y Cia,${ }^{54}$ shared with me his opinion on the subject matter. Cortina (2016) shared my view on the lack of expertise among Mexican attorneys, suggesting that foreign investors will not trust Mexican attorneys because they have the economic capacity to employ an international legal firm and will not risk in losing the controversy. ${ }^{55}$

Likewise, the Mexican government recognizes the absence of experience in investor arbitration in Mexico. Even the Secretary of Economy hires international legal firms to assist him in defending Mexico in ISDs (see Metaclad, Azinian, etc.). Hugo Perezcano shared with me that while he was representing the Mexican government in investor-State disputes (such as Metaclad, Azinian, Feldman, etc.) it was often difficult to find someone appropriate from Mexico with the qualifications to appoint as an arbitrator, especially in

54 See: wrere.chevez.com, Chevez, Ruiz, Zamarripa y Cia. It's a leading legal firm in Mexico.

55 Personal Communications with Francisco Cortina Velarde, Cortina, F. (Nov. 2016). 
Esta revista forma parte del acervo de la Biblioteca Jurídica Virtual del Instituto de Investigaciones Jurídicas de la UNAM

the earlier years. Furthermore, Perezcano pointed out that because Mexican lawyers are trained in the civil law legal system, the Secretary of Economy needed assistance especially in the oral phase of the process, because it lacked in training in advocacy skills, such as cross-examinations. ${ }^{56}$

Understandably, the solution is to promote no more Mexican investors in suing Canada or U.S. to encourage the development of the required skills of investor arbitration. There are better approaches to develop and to incite new attorneys in these matters.

\section{How to Cultivate the Expertise?}

On developing new skills, the best way is to look at exemplars. It is well known that the Secretary of Economy hires external lawyers when representing Mexico in arbitration panels. ${ }^{57}$ Perhaps, all of the expertise is being held by the Secretary of Economy, where, indisputably, its representatives are doing a highly recognized job.

In this sense, in Mexico the one with the best expertise in arbitration investment is the Secretary of Economy. It is a great option if the Secretary of Economy can commence internships for lawyers to let them gain the expertise needed in representing ISDS.

An Internship Program with the Secretary of Economy can spread the expertise and, in the future, cultivate expertise among Mexican attorneys. Perezcano (2016) shared with me the opinion that, in fact, legal firms can help promote the internships by allowing some of their seniors attorneys to work with the Secretary of Economy. ${ }^{58}$

Nevertheless, universities and institutional programs should promote legal studies in investment arbitration. As we discussed, there is an unstopping growth of international trade treaties and ISDS; it is important that Mexican legal firms grow along with the international community in developing the new legal skills that are required to compete with international legal firms.

In the last decade, universities have started educating young attorneys in alternative means of dispute resolution, supporting the education of oral trials. It has been a long process, due to the fact that Mexican attorneys are educated under the civil system, where the written law predominates and almost all trials are held by written communications.

Undoubtedly, there is a long road to go in developing Mexican expertise in investment arbitration. Trade treaties (NAFTA in particular) is becoming more

56 See: Perezcano, supra note 42.

57 See: Francisco González de Cossío, supra note 46. The author highlights that the Secretary of Economy hires external lawyers in representing Mexico in arbitration panels. Furthermore, it was shared by Hugo Perezcano (2016), that the Secretary of Economy hires international lawyers especially for the oral phase of the arbitration proceeding.

58 Id. 
Esta revista forma parte del acervo de la Biblioteca Jurídica Virtual del Instituto de Investigaciones Jurídicas de la UNAM

important every year. Mexican attorneys have already realized the need to start competing in the ISDS market and, hopefully, they will start taking measures to get there some day.

\section{Conclusion}

Finally, I would like to point out some of the conclusions reached by this paper:

- In the twenty years of NAFTA, Mexican attorneys have not been active participants of the treaty, especially in representing foreign investors in NAFTA's Ch. XI enforcement mechanism. The reasons are unclear but shared between two attorneys with enough experience in the field. However, Mexican legal firms have realized the need to develop this knowledge. Measures such as an internship program with the Secretary of Economy can help develop the expertise in the short run, and will likely encourage foreign investors to start looking at Mexican legal firms as a reliable option.

- Mexico, twenty-two years after of the adoption of NAFTA, has been constantly exposed by the tribunals for lack of transparency, acts of corruption between Mexican authorities, and lack of due process. The threats that foreign investors face in Mexico have not been diminished, taking into consideration the claims alleged in Metaclad and in B-Mex case.

- Regardless of the fact that Mexico has been able to defend the claims brought by foreign investors eagerly, ISDs have not benefitted Mexican investors. Usually Mexican investors do not understand their rights abroad and do not find within Mexico the legal support to protect their rights. As we have concluded, Mexican investors have had zero participation in NAFTA's ISDS. 